\title{
Opportunities and challenges for community-based ecotourism development: A case study in Dinsho and Goba Woredas, Southeast Ethiopia
}

\author{
Israel Petros Menbere ${ }^{1 *}$ and Timar Petros Menbere ${ }^{2}$ \\ ${ }^{1}$ Department of Biology, College of Natural and Computational Sciences, Dilla University, P.O.Box: 419, Dilla, Ethiopia. \\ ${ }^{2}$ Department of Biotechnology, Addis Ababa Science and Technology University, Addis Ababa, Ethiopia.
}

Accepted 25 May, 2017

\begin{abstract}
This study was conducted to assess the opportunities and challenges for community-based ecotourism development in Dinsho and Goba Woredas, in Ethiopia. Local communities who were participant in ecotourism, and key informants from Bale Mountains National Park, Madawalabu University, government offices and non-governmental bodies were the target groups of this study. The primary data were collected through questionnaires, interviews and field visits. Document reviews were also made to support the study. The result of the study indicated that endemic animals and plants were the main attractions of ecotourism in both Dinsho and Goba Woredas. Bodity Mountain and local culture were the second main ecotourism attractions in Dinsho and Goba Weredas, respectively. The study revealed diversification of potential ecotourism resources, existence of local institutions such as the Gada system and presence of various conservation organizations as the top three opportunities for developing community-based ecotourism in the Woredas. It has also been indicated that the communities in both areas can participate in a range of ecotourism activities such as supplying agricultural products (poultry, milk, honey and coffee), provision of accommodation facilities, handcraft selling and cultural show. As per the result of the study, inadequate infrastructure was the main challenge for community-based ecotourism development in Dinsho while awareness problem was the main challenge in Goba. The study also identified absence of sufficient accommodation with food and water services as the main ecotourism facility problem in both Woredas.
\end{abstract}

Keywords: Challenges, community-based, Dinsho, ecotourism, Goba, opportunities.

*Corresponding author. E-mail: peterisri.4banch@gmail.com.

\section{INTRODUCTION}

Tourism is one of the leading and the fastest growing industries in the world (Ketema, 2015b). It is among the main economic sectors in promoting communities development through income generation and employment opportunities. Currently, with advancement in technology and globalization, tourism demonstrates a rapid growth. For instance, in 2013, tourism contributed for $9.5 \%$ in Gross Domestic Product (GDP) of the global economy. In the same year, more than 250 million tourism jobs were created internationally (Pookhao, 2014; Torres and Momsen, 2014). Tourism also plays a significant role to the economic development of many developing countries (Torres and Momsen, 2014). For these countries, it serves as the major source of foreign exchange exceeding $80 \%$ of their total earnings (Mequanint and Gebremedhin, 2015).

The tourism industry of Ethiopia has a great developmental future, and it is in continuous growth in recent years (Bayou and Bedane, 2014; Ketema, 2015b). Particularly, in the last five years, the Ethiopian tourism industry revived in the global market due to the current peace, stability and government attention to develop the 
Table 1. The number of international tourists arrived to Ethiopia from 2000-2013 and income generated.

\begin{tabular}{cccccccc}
\hline \multirow{2}{*}{ Year } & \multicolumn{2}{c}{ Tourist arrivals } & & \multicolumn{5}{c}{ Income generated } \\
\cline { 2 - 3 } \cline { 5 - 7 } & Number & Growth in \% & & In USD & Growth in \% & In ETB & Growth in \% \\
\hline 2000 & 135,954 & & & $68,000,000$ & 102.4 & $577,800,000$ & 129.3 \\
2002 & 156,327 & 5.3 & & $77,100,000$ & 4.5 & $676,100,000$ & 7.0 \\
2004 & 184,078 & 2.3 & & $114,627,850$ & 27.4 & $994,408,000$ & 27.8 \\
2006 & 330,026 & 45.1 & & $169,975,086$ & 22.6 & $1,494,811,899$ & 24.3 \\
2008 & 383,399 & 7.1 & & $204,855,489$ & -4.2 & $1,979,539,071$ & -0.4 \\
2009 & 427,286 & 11.4 & & $246,415,374$ & 20.3 & $2,900,062,542$ & 46.5 \\
2010 & 468,305 & 9.6 & & $333,352,000$ & 35.3 & $4,800,268,804$ & 65.5 \\
2011 & 523,438 & 12.0 & & $411,638,987$ & 23.5 & & \\
2012 & 596,341 & 13.9 & & $1,190,775,613$ & & & \\
2013 & 629,768 & & $2,500,000,000$ & & & \\
\hline
\end{tabular}

Source: Ministry of Culture and Tourism Bulletin, 2013.

sector (Aynalem, 2016). In 2012, the contribution of tourism to GDP was $5.1 \%$, and the contribution for the total job opportunity was $12.3 \%$ (WTTC, 2013). There is an increase in the number of international tourists visiting Ethiopia and in the amount of income obtained from tourism (Table 1). Hence, travel and tourism is becoming one of the major economic activities in Ethiopia (Mequanint and Gebremedhin, 2015).

Ecotourism is a recent concept that emerged in the 1980 s, as an alternative form of tourism to reduce the deterioration at the tourism destinations caused by mass tourism, and to maintain the sociocultural and environmental condition of the attraction areas. It obtained the attention of developing countries due to both its importance in promoting conservation and its significance in economic development (Pookhao, 2014). It is a responsible form of tourism demonstrated as a travel to natural attraction areas that possess both scenic environmental and cultural resources, and where the scenery, flora, fauna and cultural heritage are the primary attractions (Fetene et al., 2012; Eshetu, 2014; Ofem et al., 2012). This makes ecotourism a valuable tool to enhance community based natural and cultural conservation and contribute to the welfare of local communities. Ecotourism is also supported with an inherent element of nature education to enhance customer satisfaction, in addition to marketing of the serene natural habitats as a tourism 'product' (Rajani and Vasanthakumari, 2014). Hence, ecotourism is appeared to have a paramount role for local areas in boosting the socio-economic status of communities and achieving environmental and social protection (Lushaj et al., 2012; Kiss, 2004).

Ethiopia possesses unique and highly valuable ecotourism resources. The combination of historical, cultural and natural ecotourism attractions has an indispensable role for its future growth (Meseret, 2010). The country has stunning landscapes and biodiversity, diverse culture and tradition, and ancient historical places aging as old as 3000 years. However, the ecotourism resources particularly, natural areas involving national parks are under severe degradation. As agriculture is the livelihood strategy for the majority of Ethiopians, the intensification of agricultural activities in natural areas, and the associated impacts are widely prevalent, and lead to deterioration of the environment (EFCOT, 2003). Protected areas are established to preserve the natural ecosystems and associated life features in the country, but recently, most of the Ethiopia's conservation areas experience threats and environmental degradations. Alternative livelihood options like ecotourism and community involvement in the management of natural and protected areas are not practiced in inadequate manner (Bayou and Bedane, 2014; Tucker, 2007).

The Dinsho and Goba Woredas are among the most important biodiversity and ecotourism sites in South east Ethiopia. Goba Woreda is larger in size and total number of human population, has more urbanized town and possesses large amount of natural forest coverage compared to Dinsho Woreda. Both Woredas are known by their magnificent Afromontane ecosystem and spectacular landscapes, large number of endemic flora and fauna, intact cultural resources, and holding various migrant bird species. However, the growing human population and the associated need to meet local livelihood, intensified the different pressures (Kidane et al., 2012). The major economic activities and source of income for communities in the Woredas are farming of crop and livestock that are highly dependent on the ecosystem. Given the intensive dependence of communities on the surrounding natural resource for their livelihood, the sustainability of various resources and their ecosystem benefits are hardly possible in the future. Anthropogenic activities such as illegal settlement, land clearing and deforestation, and intensified use of fire for management are identified as the key drivers of land use 
change in the Woredas (Kidane et al., 2012). The different natural ecosystems of the Woredas are also used as sources of fertile cropland and natural rangeland by local communities (Lemenih et al., 2009). As a result, overgrazing and the expansion of agricultural areas are threatening, the Afroalpine and Subafroalpine ecosystems of Dinsho and Goba Woredas (Tolla and Traynor, 2015; Temesgen, 2015; Kidane et al., 2012).

Ecotourism has a significant role to address conservation problems and generate alternative income sources for local communities (Lemenih et al., 2009). It can also contribute for socio-cultural development and sustainable use of the environmental sources (Aynalem, 2016). However, ecotourism in Ethiopia is still in its infancy and the country has not benefited the most output from its resources (Eshetu, 2014). Similarly, ecotourism development and significance in social, environmental and economical aspect is low compared to the neighboring countries (Dejene et al., 2014). The underdevelopment of ecotourism is because of insufficient infrastructure and service provision. Absence of adequate study on ecotourism potentials and the less dissemination in the ecotourism notion and approaches hinder the effective and sustainable development of the ecotourism in Ethiopia (Gebreigziabiher, 2015; Birhan and Gebreyes, 2015).

Ecotourism is also characterized by underdeveloped state in Dinsho and Goba Woredas, which possess immense ecotourism potentials, but are also places where ecosystem degradation and biodiversity threats are intense (Asmamaw and Verma, 2013; Ayele, 2011). Despite the recent growth in the number of tourists visiting the districts, the overall ecotourism is not well developed compared to resources, and so does the rate of tourist flow in the Woredas (Figure 1). Ways to improve local governance, promoting conservation and ensuring local benefits are yet to be developed (Lemenih et al., 2009). To make the natural resources more valuable to local community and to preserve the environment in a good manner, ecotourism which integrates conservation of natural areas and improves the livelihood of communities should be launched (Temesgen, 2015; Lemenih et al., 2009). Ecotourism in the Woredas can be developed by making intensive study and documentation of the potential attractions, developing good ecotourism plans, promoting the effective implementation of ecotourism strategies and generally enhancing the participation and role of all stakeholders (Ayele, 2011; Aynalem, 2016; Bale Mountain National Parks, 2014). Moreover, studying the opportunities and challenges of community-based ecotourism was found to be crucial as it indicates the gaps and advantages for ecotourism development in the Woredas (Aynalem et al., 2015). Therefore, this particular research paper has tried to identify the opportunities and challenges for developing communitybased ecotourism in Dinsho and Goba Woredas, in Ethiopia.

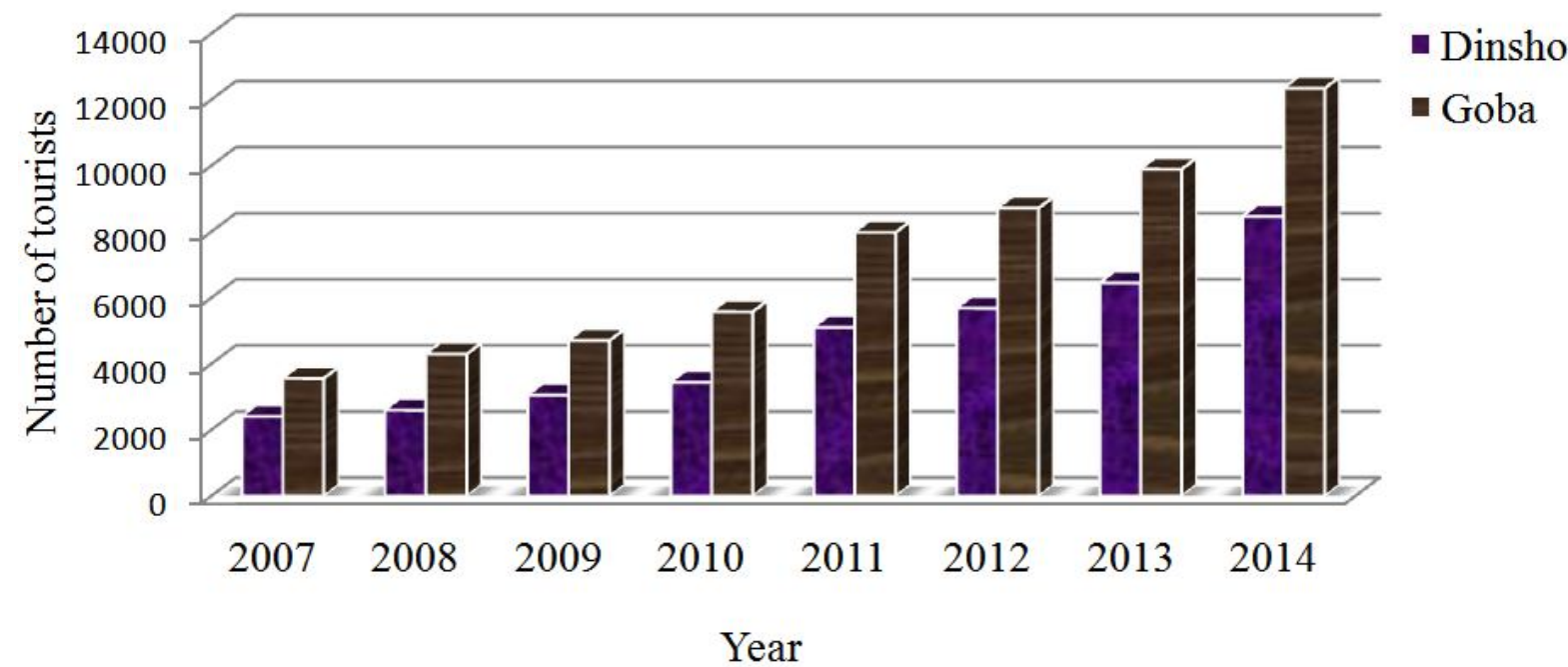

Figure 1. The rate of tourist flow in Dinsho and Goba Woredas. Source: Culture and tourism offices of Dinsho and Goba Woredas, 2015.

\section{MATERIALS AND METHODS}

The study was carried out in Dinsho and Goba Woredas. The Woreda is the second lowest administrative unit of the current
Ethiopia comprising several kebeles (composition of villages) in its local boundary. Both Woredas were selected because they entertain better ecotourism activities. Dinsho is the headquarter of the Bale Mountains National Park while Goba is the closer 


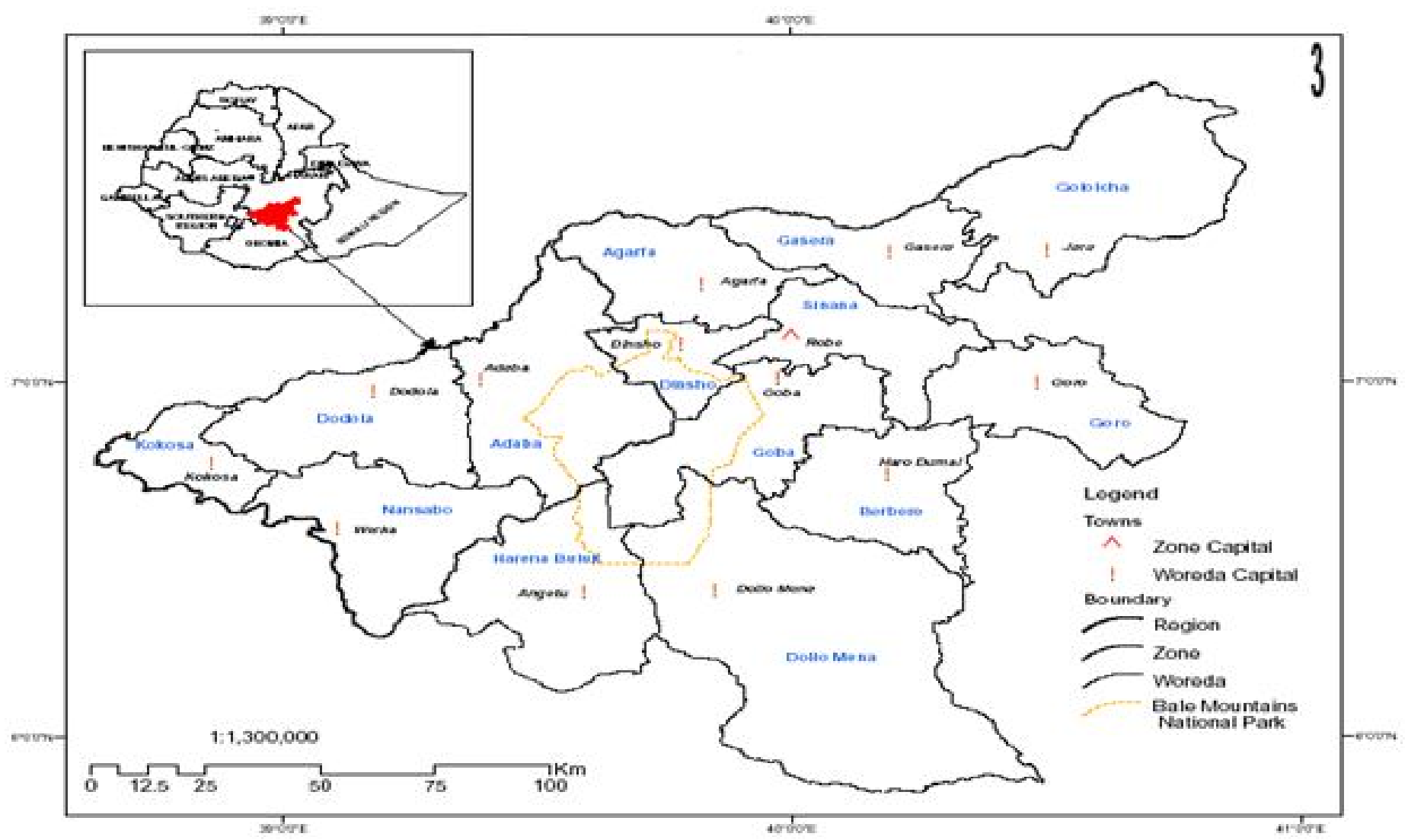

Figure 2. Map of the study area.

destination to the headquarter. Dinsho and Goba Woredas, make the northern and northeastern part of Bale Mountains National Park (BMNP), respectively (Mamo, 2007). Both Woredas are located in South eastern part of Ethiopia, found in Oromia regional state, Bale zone (Figure 2). Dinsho is $400 \mathrm{kms}$ far away from Addis Ababa whereas Goba is $455 \mathrm{~km}$ away from Addis Ababa; the capital city of Ethiopia. The 2007 national census report indicated that the total population of the Dinsho Woreda was 39,124 while the total population of the Goba Woreda was 73,653 (CSA, 2007). Both areas are characterized by cold climate type which is the characteristics of the Ethiopian highlands. The annual rainfall of the two Woredas ranges between 600 and $1500 \mathrm{~mm}$. The annual mean minimum and mean maximum temperature of the Dinsho Woreda are 2 and $20^{\circ} \mathrm{C}$ respectively. While the annual mean minimum and mean maximum temperature of the Goba Woreda are 3.5 and $32^{\circ} \mathrm{C}$, respectively.

Local comunities who were involved in ecotourism activities such as tour guides, scouts, horse renters, food makers and handcraft workers were purposely selected because they were considered knowledgeable in their view of ecotourism opportunities and challenges. A total of 94 respondents from Dinsho (16 tour guides, 29 horse renters, 15 food makers, 25 scouts and 9 handcraft workers) and 84 from Goba (10 tour guides, 25 horse renters, 22 food makers, 19 scouts and 8 handcraft workers) were selected for this study. Moreover, key informants from the BMNP, Madawalabu University, government offices and NGOs were selected purposely due to their familiarity to ecotourism development. In this way, 4 individuals from the park, 3 lecturers from Madawalabu University, 5 individuals from government offices, and 2 NGO workers were involved as the target groups for this study.

\section{Methods of data collection}

This research was conducted from October 2014 to July 2015. Different data collection methods were employed in order to control the data and maintain its credibility. To assess the opportunities and challenges for community-based ecotourism development in Dinsho and Goba Woredas, data collection tools such as questionnaire distribution, interview and field visit were incorporated. Both interview and distribution of questionnaire were undertaken to identify the opportunities and challenges for community-based ecotourism development. Field visit and photograph record were made to obtain evidences of ecotourism opportunities and challenges in the areas. In order to substantiate and support the study, document review was also conducted.

Questionnaires were administered for participant communities. They were distributed for 178 respondents purposely selected from Dinsho and Goba Woredas. Interviews were carried out with key informants from the BMNP Park, Madawalabu University, government offices and NGOs. This was conducted with purposely selected persons in both Woredas. The fourteen selected key informants were individuals having a considerable experience in ecotourism profession. Field observation and photograph record were used for the sake of verifying the result obtained from questionnaire and interview with the practical aspect on the ground. In addition, documents (case studies, publications, reports and bulletins) from Bale Mountains National Park, Farm Africa and 
Table 2. Potential attractions of ecotourism in Dinsho and Goba districts.

\begin{tabular}{lcccc}
\hline Attractions & NRDD & P & NRGD & P \\
\hline Endemic fauna and flora & 31 & 32.98 & 43 & 51.19 \\
Goba Medicinal plants field Gene bank (IBC-Ethiopia) & - & - & 2 & 2.40 \\
Museum & 2 & 2.13 & - & - \\
Rivers & 3 & 3.19 & 8 & 9.52 \\
Valley & 4 & 4.25 & 3 & 3.57 \\
Geology and glaciations & 1 & 1.06 & 3 & 3.57 \\
Local culture & 4 & 4.25 & 9 & 10.71 \\
Bodity Mountain & 18 & 19.15 & - & - \\
Fincanbera attraction site & 12 & 12.77 & - & - \\
Adele plateau & 5 & 5.32 & - & - \\
Konadira, and other historically crucial stones & 7 & 7.45 & - & - \\
Caves & 2 & 2.13 & 5 & 5.95 \\
Springs and waterfalls & 3 & 3.19 & 6 & 7.14 \\
Monasteries and religious celebrations & - & - & 2 & 2.40 \\
Others & 2 & 2.13 & 3 & 3.57 \\
\hline
\end{tabular}

NRDD: Number of respondents from Dinsho district: NRGD: Number of respondents from Goba district. P: Percentage.

Culture and tourism offices of Dinsho and Goba Woredas were included to support the study.

\section{Data analysis}

The quantitative data obtained from questionnaire was analyzed using descriptive statistical method such as percentage. Chi-square test of SPSS 20.0 version software was used to test the sociodemographic characteristics of respondents and challenges for community-based ecotourism between Goba and Dinsho districts. The qualitative data obtained through interview and field visit were analyzed in the form of narration.

\section{RESULTS AND DISCUSSION}

\section{Socio-demographic characteristics}

From the 94 respondents who were selected from communities in Dinsho Woreda, about 58 (61.70\%) were males whereas $36(38.30 \%)$ were females. The number of males was significantly higher than females $\left(X^{2}=5.149\right.$, $\mathrm{df}=1, \mathrm{p}=0.023$ ). The age structure of the respondents was characterized by $21(22.34 \%)$ in the age category between 18 and 25, $62(65.96 \%)$ between 26 and 45 and the remaining $11(11.70 \%)$ above 45 years. There was significant difference in the age category of respondents $\left(X^{2}=46.617, d f=2, p=0.000\right)$. The educational level of the respondents also showed significant variation $\left(X^{2}=\right.$ 49.191, df $=1, p=0.000) .81(86.17 \%)$ of respondents could read and write whereas $13(13.83 \%)$ could not. Of the selected 84 respondents from Goba Woreda, 50 $(59.52 \%)$ were males while $34(40.48 \%)$ were females. There was no significant difference between males and females $\left(X^{2}=3.048, d f=1, p=0.081\right)$. The age structure of the respondents was $25(29.76 \%)$ in the category between 18 and 25, 39 (46.43\%) between 26 and 45 and the remaining $20(23.81 \%)$ above 45 years. There was significant difference in the age category of respondents $\left(X^{2}=6.929, d f=2, p=0.031\right)$. The educational level of the respondents also showed significant variation $\left(\mathrm{X}^{2}=\right.$ $40.048, \mathrm{df}=1, \mathrm{p}=0.000) .71(84.52 \%)$ of respondents could read and write whereas $13(15.48 \%)$ could not.

\section{Ecotourism potentials of Dinsho and Goba Woredas}

The ecotourism resources of Dinsho and Goba Woredas are generally characterized by the amalgamation of biological, cultural and physical attractions. Of the different identified ecotourism potentials in the areas, endemic animals and plants are the main attractions of ecotourism in both Dinsho 31 (32.98 \%) and Goba 43 $(51.19 \%)$ Woredas. Bodity Mountain $18(19.15 \%)$ is the second main ecotourism attraction in Dinsho while local culture $9(10.71 \%)$ is the second main attraction in Goba Woreda. It was also revealed that Fincanbera attraction site $12(12.77 \%)$ and rivers $8(9.52 \%)$ are amongst the major attractions of ecotourism in Dinsho and Goba districts, respectively (Table 2 ).

The findings of this study revealed that both Woredas possess immense ecotourism attractions. The main ecotourism potentials of the Woredas are the endemic fauna and flora species. The areas have also ecotourism potentials such as, Bodity Mountain and Fincanbera attraction site in Dinsho Woreda, and rivers and water falls in Goba Woreda (Figure 3). This coincides with the study of (Aynalem et al., 2015), in which the Bale Mountains National Park and the associated fauna and 


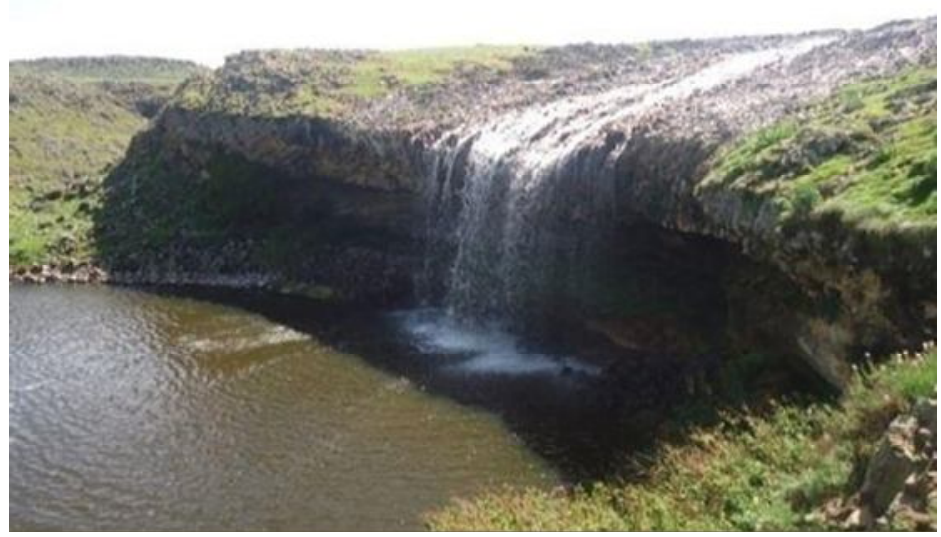

a) Fincanbera attraction site in Dinsho
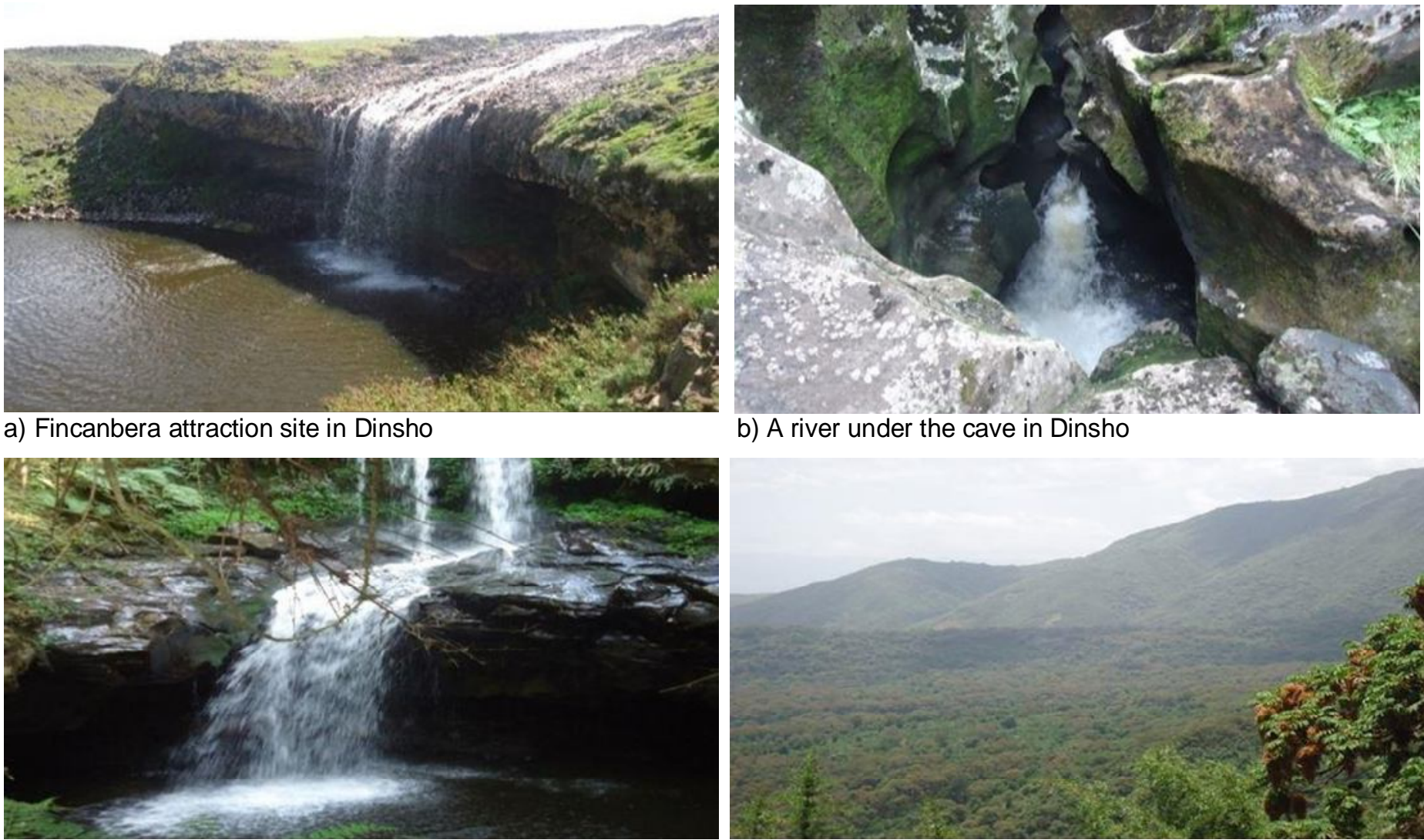

b) A river under the cave in Dinsho

c) Waterfall in Goba
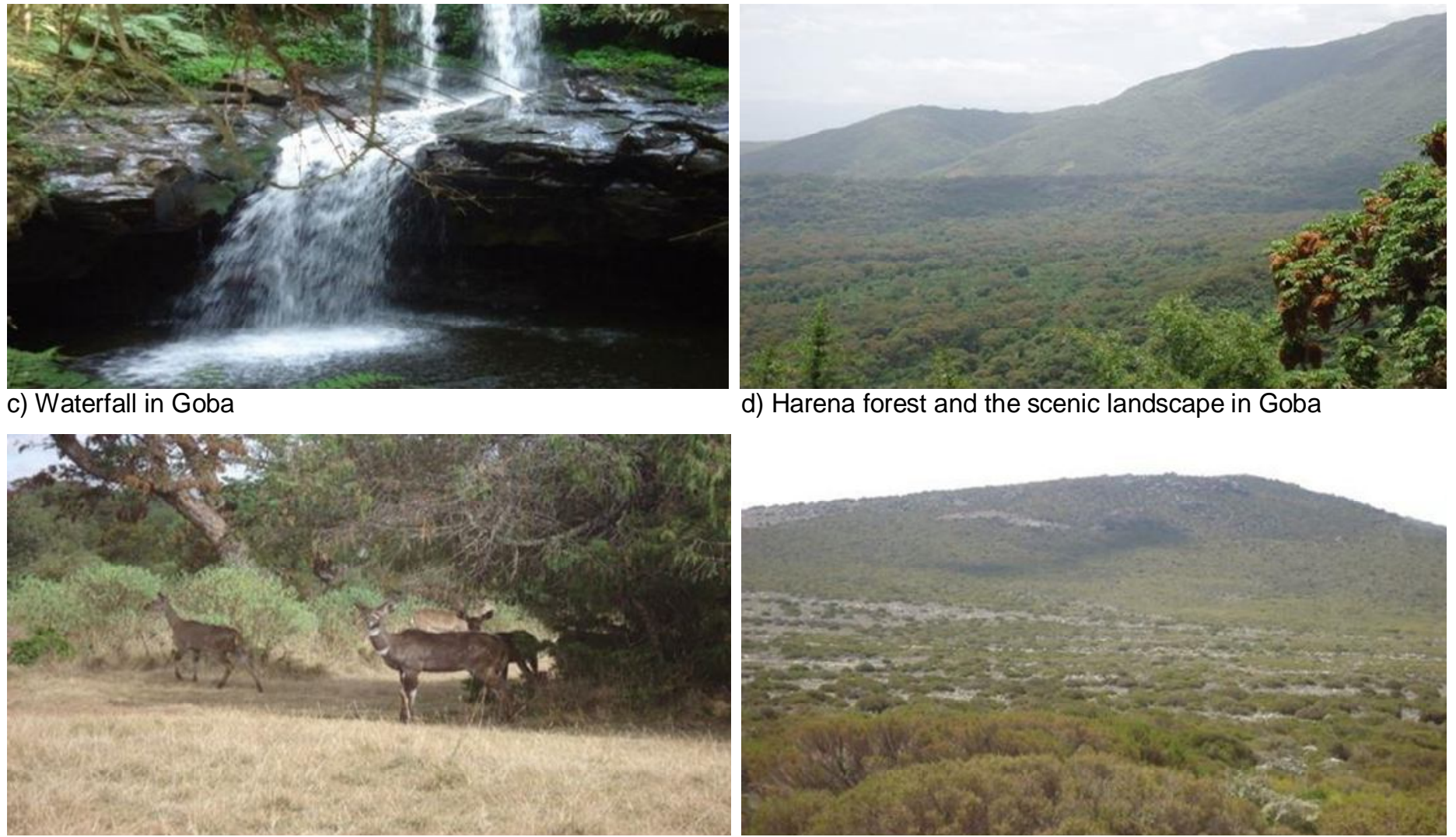

e) The endemic Mount Nyala in Dinsho

d) Harena forest and the scenic landscape in Goba

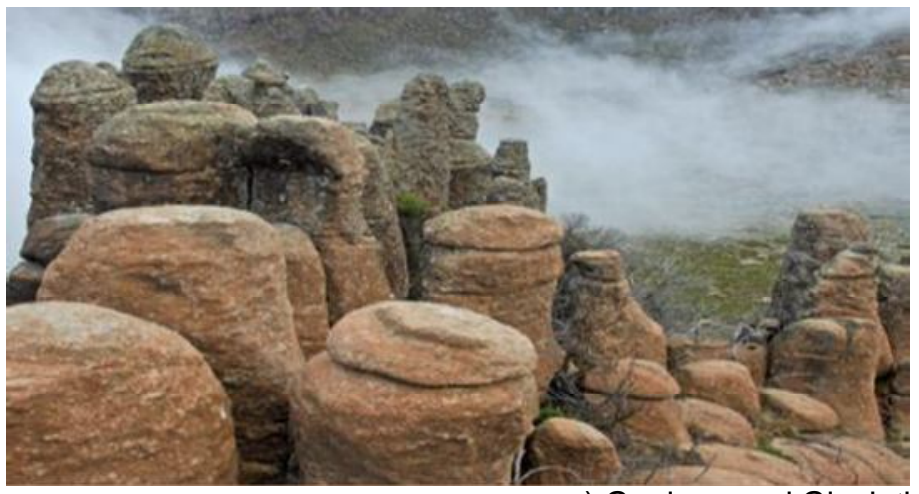

\section{f) Afroalpine ecosystem in Goba}

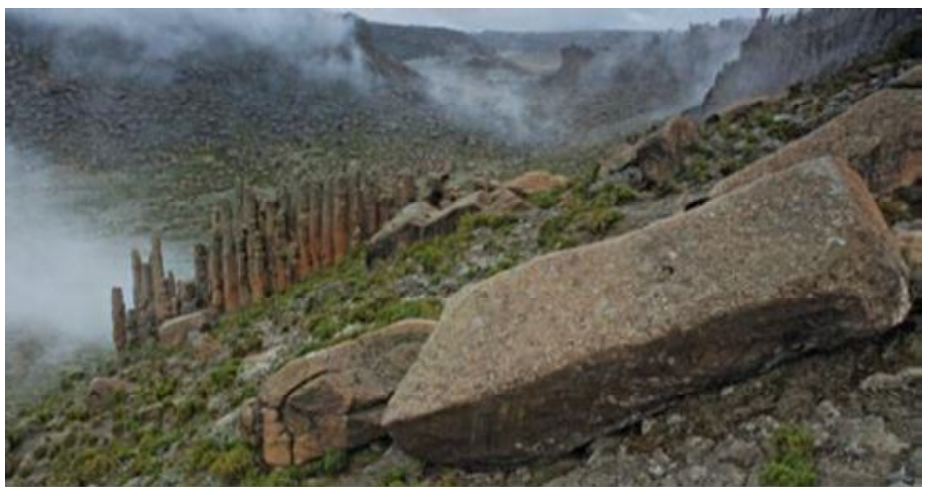

g) Geology and Glaciations in Goba 


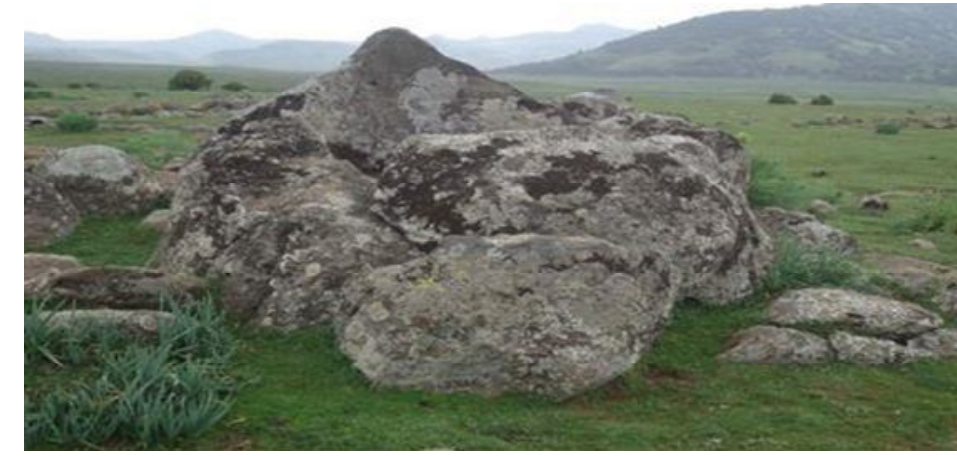

h) Historically crucial stone in Dinsho

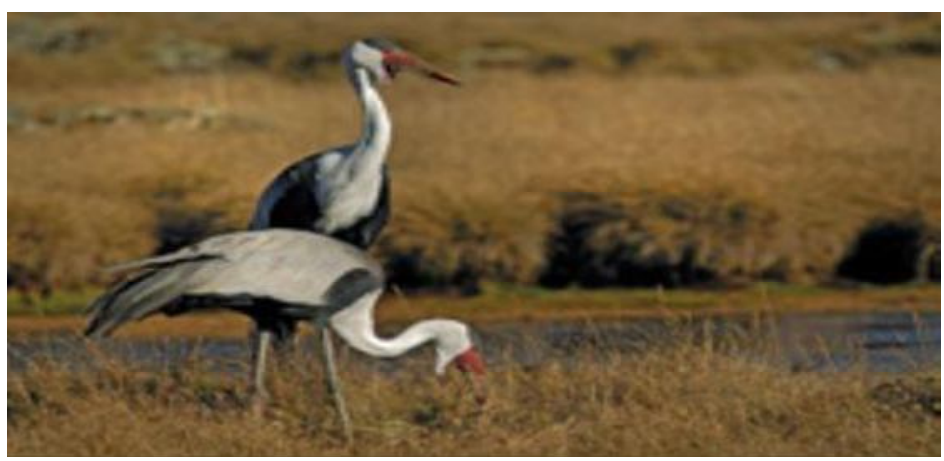

j) Wattled Crane (Bugeranus Carunculatus), Wetland bird in Goba

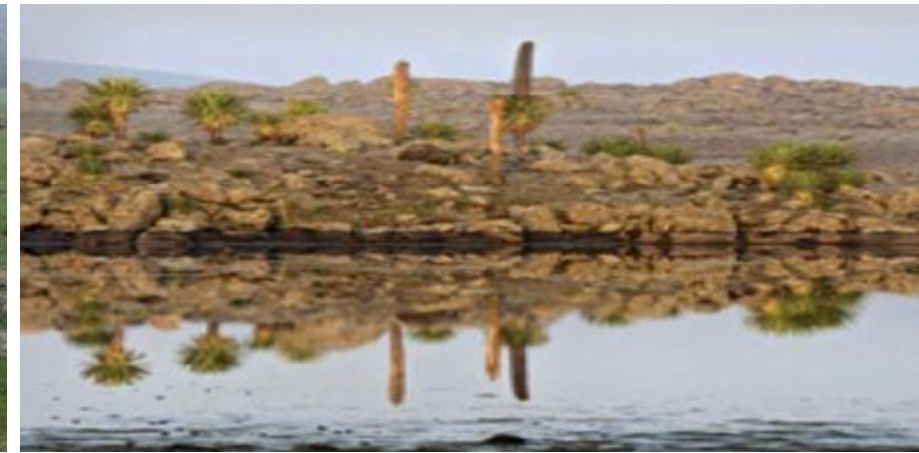

i) Giant Lobelia (Lobelia rynchopatelum)

Native plant species in Goba

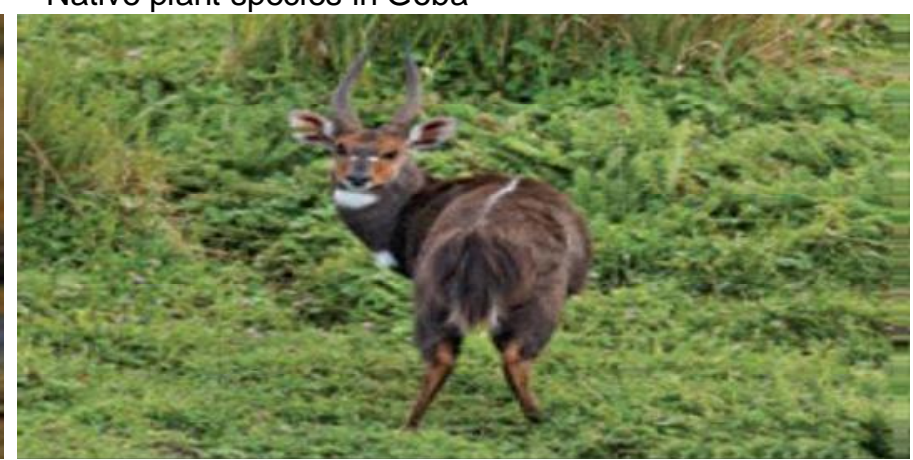

k) Menelik's Bushbuck in Goba

(Tragelaphus scriptus meneliki)

Endemic at subspecies level

Figure 3. The ecotourism potentials in Dinsho and Goba Woredas (a, b, c, d, e, f and h: Photo by: Authors, 2015; g, i, j and k: Photo from: Richman and Admassu, 2013).

flora species make up the main ecotourism attractions in the areas. In addition to the biological and physical attractions, resources for cultural ecotourism are also found in the Woredas. This was also revealed during the interview with key informants in the two districts. The mountain chains of Sennati and Gasay are pertinent to develop mountain trekking and wildlife watching as a common ecotourism activities in Goba and Dinsho Woredas, respectively (Kebede, 2007; MMA, 2009). Though not well documented, the various cultural resources of the Woredas are significant for religious and ritual purposes (Ayele, 2011). Hence, these resources are crucial for ecotourism activities such as photographing, sightseeing, trekking, wildlife viewing, sport hunting, camping, swimming, horse riding and appreciating culture.

\section{Opportunities for community-based ecotourism development in the Woredas}

The various opportunities for community-ecotourism development in the Woredas are indicated in Table 3. Diversity of attractions $43(24.16 \%)$, presence of local institution such as the Gada system $27(15.17 \%)$ and presence of conservation organizations $20(11.23 \%)$ are the main opportunities for developing community-based ecotourism in the areas. Availability of adequate human labor $18(10.11 \%)$ and presence of ecotourism support policies at national and regional level $16(8.99 \%)$ are the next great opportunities for ecotourism development of the areas. Enthusiasm of local peoples for ecotourism, infrastructural advancement and economic growth, existence of scientifically valuable sites and presence of higher education institution at nearby area are also the opportunities crucial for ecotourism development in the Woredas.

The presence of these opportunities in both Dinsho and Goba Woredas is important to promote resource conservation, improve tourism facilities, and thereby contribute for the successful development of communitybased ecotourism in the areas. According to the study of Ogato et al. (2014), the presence of opportunities like, diversity of ecotourism attractions, presence of ecotourism support policies and availability of conservation organizations favor community-based ecotourism as the same experience was observed in Wonchi ecotourism site, in Ethiopia. The existence of 
Table 3. Opportunities for community-based ecotourism development in both Dinsho and Goba Woredas.

\begin{tabular}{lcc}
\hline Opportunities of ecotourism & Count & Percentage \\
\hline Diversity of potential ecotourism resources & 43 & 24.16 \\
Presence of various conservation organizations & 20 & 11.23 \\
Local communities' enthusiasm for ecotourism & 14 & 7.86 \\
Presence of ample labor force & 18 & 10.11 \\
Existence of higher education institution at nearby area & 9 & 5.06 \\
Existence of infrastructural advancement & 11 & 6.18 \\
Economic growth and development in the Woredas & 10 & 5.62 \\
Existence of local institutions such as the Gada system & 27 & 15.17 \\
Presence of ecotourism support policies at national and regional level & 16 & 8.99 \\
Existence of scientifically valuable areas in the Woredas & 10 & 5.62 \\
\hline
\end{tabular}

local institution such as the Gada system is crucial to promote community-based ecotourism initiative in an area (Alemayehu, 2011). Similarly, availability of huge labor force can also enhance community-based ecotourism since ecotourism is one of the labor intensive economic sectors (Kidane-Mariam, 2015). The key informants in both Woredas also confirmed the presence of these opportunities and their relevance for community based ecotourism in a great manner.

\section{Possibilities for community participation in ecotourism activities of Dinsho and Goba Woredas}

According to the response of participant communities and the result from interview with key informants, enthusiasm of local peoples for ecotourism was distinguished as one of the opportunities for community-based ecotourism in the areas, 14 (7.86\%) in Table 3. Correspondingly, the key informants' interview and field observation made in the Woredas indicated a range of activities in which the communities of both areas can take part in ecotourism. As the local peoples of the Woredas rear livestock, they can provide poultry and milk products for lodges, hotels and restaurants. Goba Woreda has immense potential for honey production, but its supply as a service product in ecotourism is limited. Coffee program in different tourism destinations of the Woredas appears to be another potential that has not been exploited in adequate manner. Local people's involvement in the provision of these services is vital to relate ecotourism with the existing livelihood activities such as agriculture. This linkage of ecotourism and local activity is important in that the majority of communities whose livelihood depends on agriculture can subsist through ecotourism (Dejene et al., 2014). There is also more problem and scarcity of accommodation facility in both Woredas. The tourism amenities such as lodges, camps and ecotourism materials are not mostly provided by the local communities in Dinsho and Goba Woredas (Ayele, 2011).
This makes this sector open for further development of the service delivery. Handcraft selling and cultural show are the other opportunities. Involving in the provision of these products helps communities to create alternative livelihood options and earn income. By sharing cultural performances like festivals, producing natural products and supplying local handcrafts, the local communities in the Woredas can participate in ecotourism (Aynalem et al., 2015). This type of communities' participation in ecotourism is vital to improve their living conditions and at the same time enhance conservation through ecotourism (Honey, 2002). If effectively undertaken, ecotourism development in the areas can be a sustainable way to protect the natural environment and create socioeconomic, cultural and ecological benefits for local communities (Ofem et al., 2012).

\section{Challenges of ecotourism development in Dinsho and Goba Woredas}

The challenges of ecotourism development in both Woredas are illustrated in Table 4 . The study revealed, inadequate infrastructure as the main challenge of ecotourism 19 (20.21\%) in Dinsho while awareness problem as the main challenge in Goba Woreda 20 $(23.81 \%)$. Lack of financial capacity and unsustainable use of resources are both the second main challenges in Dinsho 17 (18.08\%) and Goba 11 (13.10\%) Woredas, respectively. Lack of adequate skilled man power, lack of strong collaboration among stakeholders, pollution, deforestation and others are the remaining challenges with a record of less than $10 \%$ in both Woredas. However, only inadequate infrastructure showed significant difference between the two Woredas $\left(X^{2}=\right.$ 8.167, $\mathrm{df}=1, \mathrm{p}=0.004$ ) (Table 4).

Among the revealed contending factors in Dinsho and Goba Woredas, absence of adequate infrastructure and the low level community awareness towards ecotourism were found to be the main challenges for ecotourism 
Table 4. Challenges of ecotourism development in Dinsho and Goba Woredas.

\begin{tabular}{|c|c|c|c|c|c|c|c|}
\hline \multirow{3}{*}{ Challenges } & \multicolumn{4}{|c|}{ Woredas } & \multirow{3}{*}{$x^{2}$} & \multirow{3}{*}{ df } & \multirow{3}{*}{$P$ value } \\
\hline & \multicolumn{2}{|c|}{ Dinsho } & \multicolumn{2}{|c|}{ Goba } & & & \\
\hline & $\mathbf{N}$ & $\%$ & $\mathbf{N}$ & $\%$ & & & \\
\hline Inadequate infrastructure & 19 & 20.21 & 5 & 5.95 & 8.167 & 1 & 0.004 \\
\hline Lack of adequate skilled man power & 3 & 3.19 & 6 & 7.14 & 1.000 & 1 & 0.317 \\
\hline Awareness problem & 13 & 13.83 & 20 & 23.81 & 1.485 & 1 & 0.223 \\
\hline Inadequate promotion of the site & 10 & 10.64 & 7 & 8.33 & 0.529 & 1 & 0.467 \\
\hline Lack of teamwork among stakeholders & 5 & 5.32 & 6 & 7.14 & 0.091 & 1 & 0.763 \\
\hline Unsustainable use of resources & 12 & 12.77 & 11 & 13.10 & 0.043 & 1 & 0.835 \\
\hline Overgrazing and illegal settlement in natural forests of (BMNP) & 4 & 4.26 & 9 & 10.71 & 1.923 & 1 & 0.166 \\
\hline Pollution & 3 & 3.19 & 4 & 4.76 & 0.143 & 1 & 0.705 \\
\hline Deforestation for agriculture & 6 & 6.38 & 3 & 3.60 & 1.000 & 1 & 0.317 \\
\hline Lack of financial capacity & 17 & 18.08 & 9 & 10.71 & 2.462 & 1 & 0.117 \\
\hline Others (i.e. fire incidence, poaching) & 2 & 2.13 & 4 & 4.76 & 0.667 & 1 & 0.414 \\
\hline
\end{tabular}

$\mathrm{N}$ : Number of respondents, \%: Percentage, (BMNP, in bracket represents Bale Mountains National Park).

development (Asmamaw and Verma, 2013; Aynalem et al., 2015; Bale Zone Culture and Tourism Office, 2014). Despite the challenges that occur in both Woredas, their intensity varies depending on various factors. Dinsho is the headquarters of Bale Mountains National Park as a result, it is the center for conservation workers, researchers and different office tasks. This might be the cause for better ecotourism awareness to exist among communities of Dinsho compared to Goba. Proximity to the park headquarters (that is, Dinsho for Bale Mountains National Park) and the presence conservation workers and researchers, contribute for prevalence of ecotourism awareness and activities (Ayele, 2011). Absence of adequate understanding of ecotourism and differences in understanding of ecotourism among stakeholders hinder the effective implementation of ecotourism and its sustainable development. This is due to inadequate knowledge of ecotourism results in the uncertainty of the policy, planning and development structures of the sector (Magio et al., 2013). In contrast to Dinsho, Goba Woreda experiences less challenge of inadequate infrastructure and facility deficiencies. This may be due to the presence of urbanized town and associated private service businesses. Community-based ecotourism development depends on quality of infrastructure and the local community awareness towards ecotourism. And, if there are problems of awareness gap and insufficient infrastructure in destination areas, the development of ecotourism becomes unsuccessful (Aynalem and Simane, 2016). The community-based ecotourism development of Dinsho and Goba Woredas is also affected by inadequate financial capacity. This problem is relatively higher in Dinsho Woreda because of factors such as the less involvement of private business owners, limited livelihood option of communities, insignificant earnings obtained from tourism, inadequate financial support from stakeholders and generally the insufficient effort made to generate income by participant groups hinder ecotourism development in the area. According to Ogato (2014), lack of financial capacity is a barrier to successful development of community based-ecotourism.

The resources of the areas are facing threats due various anthropogenic factors such as conversion of natural forest to agriculture land. As a result, unsustainable use of these resources is also among the main challenges of community based-ecotourism development in the Woredas. For instance, cropland expansion in Goba districts in 1986 was $303 \mathrm{~km}^{2}$, but in 2006 it was $396 \mathrm{~km}^{2}$. It has shown an increase in $93 \mathrm{~km}^{2}$, which is about $30.7 \%$ increase (FARM Africa and SOS Sahel, 2007). Absence of conservation and sustainable utilization of resources prohibit community-based ecotourism development and its various contributions for local communities (Dejene et al., 2014).

While the Woredas diverse physical, biological and cultural resources provide excellent opportunities for the development of community-based ecotourism, inadequate promotion of the site, absence of strong stakeholders collaboration and shortage of adequate skilled man power are the challenges facing the ecotourism destinations in the Woredas. The low level of tourism development in Ethiopia is often attributed to lack of coordination among the responsible organs, weak promotion, lack of trained manpower, and knowledge and management capacity (Kidane-Mariam, 2015; Asmamaw and Verma, 2013). Problems of overgrazing, illegal settlement in natural forest, deforestation, pollution and fire incidence are the causes for environmental degradation, and hurt the ecotourism development in the Woredas. In Goba Woreda, overgrazing and illegal settlement and the resulted land conversion were found to be highly prevalent while in Dinsho, deforestation is the 
Table 5. The forest fire occurred in the Goba and Dinsho Weredas with the type of burnt vegetation.

\begin{tabular}{llcc}
\hline & Vegetation type & Burnt area in ha & Total in ha \\
\hline \multirow{2}{*}{ Goba } & Ericaceous vegetation & 5,974 & \\
& Bamboo & 1,000 & 6,979 \\
& Hagenia based forest & 5 & \\
Dinsho & Ericaceous vegetation & 2,710 & 2,710 \\
\hline
\end{tabular}

Source: Anteneh and Temesgen, 2009.

widespread challenge of ecotourism in addition to livestock grazing. According to the study conducted by Asefa et al. (2015), signs of livestock grazing were recorded in 42 positions on transects $(70 \%)$ in the protected forests of Northern woodland habitat which is part of the Bale Mountains National Park and is found in Dinsho Woreda. Of these signs, $20 \%$ were categorized to be heavy grazing while $45 \%$ were categorized to be light grazing. The Bale Mountains National Park, which lies in these two Woredas, faces pollution problem due to the main road which is used to interconnect the different districts through land transport (cars). In relation to this, wastes improperly thrown are leading to garbage accumulation in human inhabited parts of the park. Car washing activity within the park affects the rivers, and is becoming one source of pollution mainly in Dinsho Woreda. On the other hand, fire incidence is causing vegetation loss and habitat degradation in the areas (Table 5). This has an impact on the overall functioning of the ecosystem. This indicates the necessity of wise natural resources use, and ecotourism development is therefore, important to stimulate economic development, social wellbeing of the people, and at the same time preserve the natural environment and cultural heritage of the areas (Odede et al., 2015). Ecotourism offers a winwin-situation for the benefit of the environment and the local economy (Muhanna, 2006).

The various identified opportunities are crucial for developing community-based ecotourism in both Dinsho and Goba Woredas. Diversity of ecotourism attraction is the major opportunity, and is the foundation for the development of ecotourism in the areas as communitybased ecotourism primarily depends on the natural attraction resources. Presence of local institution such as the Gada system and existence of conservation organizations are also important in that they contribute for the sustainable management of the resources. Availability of huge labor force is another opportunity of ecotourism development in the Woredas. Visitors demand diverse and quality goods and services to meet their maximum satisfaction, as a result, presence of huge labor force is vital to deliver the required facilities and services in proper manner. Similarly, existence of ecotourism support policies was also identified as an opportunity in Dinsho and Goba districts. It encourages the involvement of stakeholders in ecotourism. However, these opportunities have limited contribution for ecotourism development in Dinsho and Goba Woredas. The ecotourism development of the Woredas is also challenged by different factors. Inadequate infrastructure and lack of financial capacity were the leading factors in Dinsho while awareness problem and unsustainable use of resources were the major challenges of ecotourism in Goba Woreda. Lack of adequate skilled man power is the major problem of Dinsho district. Inadequate promotion of the site, lack of strong collaboration among stakeholders and unsustainable use of resources are hindrances of ecotourism development in both Dinsho and Goba Woredas. As a result, the implementation of communitybased ecotourism has been scantily undertaken in both Woredas.

To make use of the existing ecotourism opportunities, and reduce the different challenges of ecotourism in the Woredas, focusing on particular ecotourism questions of the areas is necessary as ecotourism development depends on particular questions in a region (Magio, 2013). Stakeholders participating in the provision ecotourism facilities and services should be encouraged. Working in collaboration with different tourism agents is also recommended. These are essential to alleviate facility, infrastructure and financial limitations. They can also lead to effective promotion of the site when they are done using the icon species in both Woredas. In the same manner, awareness problem and inadequate skilled man power challenge ecotourism development of the areas, consequently, awareness creation activities and trainings should be offered on continued base in Dinsho and Goba districts. This can be done along with universities to fill the gap in skilled human capacity. The awareness, available training and perception of communities living close to tourist destinations have an influence on their attitude towards participating and being involved in ecotourism activities (Folusade and Abayomi, 2016). There is also a need for effective co-ordination of the various stakeholders for ecotourism development in the Woredas. In addition, the direct contribution of organizations in ecotourism development of the Woredas should be promoted. Governments, the private 
enterprises, local communities, and NGOs all have vital roles to play in the area of eco-tourism development (Aynalem and Simane, 2016).

Ecotourism promotes community empowerment, and leads to address the various challenges affecting the natural resources. This is attributed to ecotourism importance in improving the community life standard and increasing disposable income of individuals. Hence, if alternative income generation is strengthened through ecotourism, it is important to enhance the financial capacity of local peoples which is one mechanism of community empowerment, and is the underlying concept in community-based ecotourism (Isaac and Wuleka, 2012). For effective and sustainable management of natural areas, development must start with the people first, and hence the involvement of local peoples in community-based ecotourism allows them to avoid many undesirable engagement in the environment (Patwal, 2013). A study of pollution particularly, in BMNP should be encouraged to reduce its impacts. Moreover, low enforcement and implementation are crucial to address the different conservation threats in the areas.

\section{Ecotourism facility problems in Dinsho and Goba Woredas}

As to the result obtained from respondents and site observation made in the areas, absence of sufficient accommodation with food and water is the main deficiency for community-based ecotourism development in both Dinsho 28 (29.80\%) and Goba 30 (35.71\%) Woredas. Inadequate communication service 22 $(23.40 \%)$ and materials absence for ecotourism activities $24(28.57 \%)$ are both the second shortages for community-based ecotourism development in Dinsho and Goba Woredas, respectively. Deficiency of quality guides $19(20.21 \%)$ and insufficient transportation service 14 $(14.89 \%)$ are ranked third and forth problems in Dinsho Woreda. Goba Woreda entertained inadequate communication service $12(14.30 \%)$ and deficiency of quality guides $10(11.90 \%)$ which are judged third and fourth, respectively. The least shortage in Dinsho Woreda is materials absence for ecotourism activities 11 (11.70 $\%)$ while insufficient transportation $8(9.52 \%)$ is the least facility shortage in Goba Woreda. This is in line with the study of (Aynalem and Simane, 2016), in which the ecotourism facilities in Dinsho and Goba Woredas such as accommodation, communication, public and institutional related services are low in terms of quality and quantity. The presence of well developed transportation service and human capacity at managerial and operational levels such as well skilled guides are very crucial for community-based ecotourism development in an area (Kidane-Mariam, 2015). The availability of adequate facilities is critical to attract more visitors to the destinations and maximize the length of stay of visitors thereby attain the required profit from community-based ecotourism (Ketema, 2015a).

\section{CONCLUSION}

The result of the study indicated that endemic animals and plants were the main attractions of ecotourism in both Dinsho and Goba Woredas. Diversification of potential resources and the existence of local institution such as the Gada system are the opportunities for developing ecotourism in the Woredas. Conversely, factors such as inadequate infrastructure, awareness problem and insufficient accommodation facilities were the main challenges that made the ecotourism development of the Woredas to remain insignificant. The participation and collaboration of different ecotourism stakeholders is suggested to address the challenges and promote ecotourism in the areas. Awareness creation, ways of income generations through ecotourism and direct organizations contribution for ecotourism are also recommended for the sustainable development of community-based ecotourism in the Woredas.

\section{ACKNOWLEDGEMENTS}

The authors would like to thank the respondents cooperated in the data collection process. The authors also extend their thanks to Ibrahim Dotore for sharing his professional experience.

\section{REFERENCES}

Alemayehu D, 2011. Challenges and Opportunities for the Establishment of Community-based Ecotourism in the Awash National Park Area. MSc thesis, Addis Ababa University, Addis Ababa.

Anteneh B, Temesgen Y, 2009. Extensive forest fire of 2007/2008 in the Bale Mountains National Park of southeast Ethiopia: extent, causes and consequences. In: Ensermu Kelbessa and Abenet Girma (eds). Tackling the frequent forest fire incidence in Ethiopia. Proceeding of a workshop. Occasional report No. 2/2009. pp. 47-76.

Asefa A, Shimelis A, Kinahan AA, 2015. Assessment of threat status in the Northern woodlands of the Bale Mountains, Ethiopia: Indicator for Management Effectiveness. Ethiopian J Environ Stud Manag, 8: 318329

Asmamaw D, Verma A, 2013. Local attitudes towards environmental conservation and ecotourism around Bale Mountains national park, Ethiopia. Scholarly J Agric Sci, 3: 506-514.

Ayele AM, 2011. Ecotourism as a sustainable development option: case study from Bale Mountains National Park. MA thesis, Addis Ababa University, Addis Ababa. pp.1-124.

Aynalem S, Akele B, Alemayehu H, Molla G, 2015. Assessment and Identification of the Tourism Resources of Bale Zone, Ethiopia. J Tour Hosp, 4: 1-5.

Aynalem S, 2016. Key stakeholders' roles and tourism development in Bale Zone, Ethiopia. World Acad J Bus Manag Admin, 1: 1-4.

Aynalem S, Simane B, 2016. Development of community-based ecotourism, a case of Choke Mountain and its environs, Ethiopia: Challenges and opportunities. J Tour Hosp Sport, 16: 14-21.

Bale Mountains National Park, 2014. Annual Magazines. 
Bale Zone Culture and Tourism Office, 2014. Annual report.

Bayou HH, Bedane AF, 2014. Factors affecting development of tourism in Oromia Rift Valley lakes area, in Ethiopia. Int J Bus Manag, 4: 6388.

Birhan M, Gebreyes G, 2015. Review on problems, prospects and economic contribution of wildlife management and ecotourism in Ethiopia. J Vet Sci Technol, 6: 1-5.

CSA, 2007. Central Statistics Agency of Ethiopian, Population Census.

Culture and tourism offices of Dinsho and Goba, 2015. Visitor statistics record of Dinsho and Goba Woredas, 2007-2014.

Dejene SW, Seyoum H, Ready RU, 2014. Ecotourism potential and its role for sustainable development and livelihood in Awash National Park, Ethiopia. Int J Sci Res, 3: 792-796.

EFCOT (Ethiopia Forum for Community Based Tourism), 2003. A study into recommendations on establishment of Community Based Tourism Organization to promote, support the growth of Community Based Tourism in Ethiopia and to represent those involved in it. Report paper by consultancy team, November/December pp. 4.

Eshetu AA, 2014. Ecotourism as a viable strategy for livelihood diversification and sustainable natural resource management in Ethiopia (from eco-development paradigm point of view). J Environ Sci Water Res, 3: 40-52.

FARM Africa, SOS Sahel BERSMP, 2007. Community profile and settlement dynamics in four Woredas of Oromiya National Regional State: Dallo Mena, Harana Buluk, Goba and Nansabo, a Final Report. IRIS Consult P.L.C., Addis Ababa. pp. 1-33.

Fetene A, Bekele T, Tiwari P K, 2012. The contribution of ecotourism for sustainable livelihood development in the Nech Sar National Park, Ethiopia. Int J Environ Sci, 1: 19-25.

Folusade AC, Abayomi AE, 2016. Adjacent communities' awareness and involvement in ecotourism activities of Kainji lake (Nigeria) and Mole (Ghana) national parks. IIARD Int J Geogr Environ Manag, 2: 1 8

Gebreigziabiher AA, 2015. An assessment of potential resources of tourism development in Ethiopia. The case of Dejen Wereda. Afr $\mathrm{J}$ Hist Culture, 7:100-108.

Honey M, 2002. Ecotourism and Certification: Setting Standards in Practice. Island Press, Washington DC.

Isaac K, Wuleka CJ, 2012. Community-based ecotourism and livelihood enhancement in Sirigu, Ghana. Int J Human Social Sci, 2: 97-108.

Kebede Z, 2007. Implementation of Shaya Community Based River Management-Ecotourism, in Bale Eco-region, in Ethiopia. Consultancy Report Presented to BERSMP, Bale Zone, Goba.

Ketema TD, 2015a. Development of community based ecotourism in Wenchi Crater Lake, Ethiopia: Challenges and prospects. J Hosp Manag Tour, 6: 39-46.

Ketema DT, 2015b. Inside the commons of ecotourism development in Ethiopia: Strategic communal empowerment or marginalization? Evidence from Wenchi community based ecotourism. Int $\mathrm{J}$ Biodiversity Conserv, 7: 429-434.

Kidane Y, Stahlmann R, Beierkuhnlein C, 2012. Vegetation dynamics, and land use and land cover change in the Bale Mountains, Ethiopia. Environ Monitor Assess, 184: 7473-7489.

Kidane-Mariam T, 2015. Ethiopia: Opportunities and challenges of tourism development in the Addis Ababa-upper rift valley corridor. $J$ Tour Hosp, 4: 1-9.

Kiss A, 2004. Is community-based ecotourism a good use of biodiversity conservation funds? Trend Ecol Evolut, 19: 232-237.

Lemenih M, Mesfin D, Kindu M, Abebaw D, 2009. Benefit Sharing Mechanisms for the Bale Eco-Region Sustainable Management. Implemented by FARM-Africa/ SOS Sahel collaboration with the Oromia region Forest Enterprises Supervisory Agency, a Final Report. pp: 1-50.

Lushaj A, Lushaj A, Seenappa SN, Butina-Watson G, Lushaj B, Malsia V, Doçi D, Hunt M, Buçpapaj E, 2012. Challenges and opportunities for biodiversity conservation and sustainable development of ecotourism in Lalzi Bay, Durres County, Albania - Today's science for tomorrow's management. A methodology guide with a concrete example by Lalzi Bay, Durres County, Albania. Int J Soc Behav Educ Econ Bus Ind Eng, 6: 625-642.
Magio KO, Velarde MV, Santillán MAN, Ríos CAG, 2013. Ecotourism in developing countries: A critical analysis of the promise, the reality and the future. J Emerg Trend Econ Manag Sci, 4: 481-486.

Mamo Y, 2007. Ecology and Conservation of Mountain Nyala (Tragelaphus Buxtoni: Lydekker 1910) in Bale Mountains National Park, Ethiopia. PhD thesis, Aberdeen University, Aberdeen.

Mequanint F, Gebremedhin S, 2015. Contribution of local community for Ecotourism Development in and around Abijata-Shalla Lakes National Park with Emphsis to Women's Role, Ethiopia. Australasian J Soc Sci, 1: 1-19.

Meseret C, 2010. Mammalian diversity in Borena Sayint National Park, South Wollo, Ethiopia. MSc. Thesis, Addis Ababa University, Ethiopia.

Ministry of Culture and Tourism, 2013. Ministry of Culture and Tourism Federal Democratic Republic of Ethiopia Tourism Statistics Bulletin 1998-2013; http://www,UNESCO.org/tourism marketing and promotion on Africa, Addis Ababa, Ethiopia.

MMA, 2009. Value Chain Options: Bamboo, Honey, Coffee and EcoTourism in Bale, Ethiopia. A final report. BERSMP and MMA, Goba. pp: 1-37.

Muhanna E, 2006. Sustainable tourism development and environmental management for developing countries. Prob Perspect Manag, 4: 14-30.

Odede FZA, Hayombe PO, Agong SG, 2015. Ecotourism for community empowerment and social inclusion: The case of Abindu sacred site in Kisumu County, Kenya. J Econ Sustain Dev, 6: 7-15.

Ofem OO, Lifu FL, Ogar IJ, Eja El, Ajadi BS, 2012. Potentials of developing the cross river state national park as an ecotourism resort, Nigeria. Acad Res Int, 2: 549-555.

Ogato GS, 2014. Planning for sustainable tourism: Challenges and opportunities for ecotourism development in Addis Ababa, Ethiopia. Am J Human Ecol, 3: 20-26.

Ogato GS, Abdise F, Gammie T, Abebe W, 2014. Promoting rural local development: The case of Wonchi Ecotourism Society, West Shoa Zone, Ethiopia. Prime J Soc Sci, 3: 662-673.

Patwal AS, 2013. The contribution of ecotourism for sustainable livelihood development in Rajaji National Park Uttarakhand. J Environ Sci Sustain, 1: $108-112$.

Pookhao N, 2014. Community-based ecotourism: The transformation of local community. SHS Web of Conferences, 12:1-8.

Rajani P, Vasanthakumari P, 2014. Ecotourism: challenges and opportunities in Kerela State, India. Contemp Res India, 5: 48-54.

Richman E, Admassu B, 2013. A travelers guide book of Bale Mountains National Park. Frankfurt Zoological Society and the Bale Mountains National Park. Ethiopian Wildlife Conservation Authority (EWCA). Addis Ababa. pp: 1-77.

Temesgen G, 2015. Threats of Bale Mountains National Park and solutions, Ethiopia. J Phys Sci Environ Stud, 1: 10-16.

Tolla T, Traynor C, 2015. Report of the Community Conservation Resilience Initiative in Ethiopia, Global Forest Coalition, Asunción, Paraguay. pp: 1-36.

Torres R, Momsen JH, 2004. Challenges and potentials for linking tourism and agriculture to achieve pro-poortourism objectives. Prog Devel Stud, 4: 294-318.

Tucker H, 2007. Undoing shame: Tourism and women's work in Turkey. J Tour Cult Change, 5: 87-105.

WTTC, 2013. Travel and tourism economic impact. World Travel and Tourism Council, Ethiopia.

Citation: Menbere IP, Menbere TP, 2017. Opportunities and challenges for community-based ecotourism development: A case study in Dinsho and Goba Woredas, Southeast Ethiopia. Int J Ecol Ecosolution, 4(1): 5-16. 